\title{
Designing Interactive Digital Media for Jakarta's Historical Sites as a Medium for Conservation and Placemaking
}

\author{
Sigit Adinugroho', Intan Rizky Mutiaz ${ }^{2}$ \\ 1,2 Master of Design in Game Technology, Animation \& Digital Media, \\ Faculty of Arts \& Design, Institut Teknologi Bandung \\ Jl. Ganesha 10, Bandung \\ E-mail: sigit.adinugroho@gmail.com
}

\begin{abstract}
Jakarta's history spanned from the $4^{\text {th }}$ century $\mathrm{AD}$, observed an intensive development during the Dutch colonial period between $17^{\text {th }}$ to the $19^{\text {th }}$ century AD, and left the Republic of Indonesia with immense infrastructural and cultural vestiges. The city, then called Batavia, was a significant political and economical center for the Dutch. Despite its importance as a living museum, many of the historical sites are now in the brink of extinction. Some were conserved, some others were converted and the rest were neglected. The Old Town (Old Town), which holds the most significant historical value, has undergone many conservation efforts, but remains hardly representable to visitors. Interactive digital media proves to be one of the most ubiquitous, versatile and cost-effective mediums to aid with presenting information, reaching an audience and educating communities. This paper attempts to relate the problem with a solution within the interactive media spectrum. It started with qualitative research which included studies in conservation, history, digital product design and interviews with topic experts and field observations. During the design and development phase, rapid iteration and prototyping were used. The result is a concept of an interactive mobile application that acts as a travel guide for Jakarta's historical sites.
\end{abstract}

Keywords: Batavia, digital, historical, interactive, media, Jakarta, old town, tourism, travel.

\begin{abstract}
Abstrak
Sejarah Jakarta terbentang mulai dari abad ke-4 Masehi, mengalami perkembangan pesat pada masa pemerintahan Belanda antara abad ke-17 hingga 19 Masehi, dan mewarisi Republik Indonesia dengan peninggalan-peninggalan infrastruktur serta kultural di kota ini. Kota yang dulunya disebut Batavia ini merupakan pusat pemerintahan dan ekonomi yang penting bagi Belanda. Signifikansi situs-situs historis Jakarta sebagai "museum hidup" di masa kini tidak sejalan dengan keadaannya yang terancam punah. Ada situs yang dilindungi, ada yang dikonversi dan sisanya dibiarkan saja. Wilayah Kota Tua mengandung nilai-nilai historis paling kental di antara semua tempat di Jakarta, menurut observasi, tidak terawat dan kurang layak dijadikan objek wisata. Media digital interaktif berpotensi untuk membantu menyajikan informasi, mencapai audiens dan memberikan edukasi pada masyarakat. Penelitian ini berusaha untuk mengkaitkan masalah konservasi situs historis Jakarta dengan spekstrum media interaktif. Ia dimulai dengan riset kualitatif mengenai konservasi, sejarah dan desain produk digital, dilengkapi wawancara dengan ahli sejarah dan observasi langsung ke lapangan. Proses iterasi cepat digunakan dalam fase perancangan dan pengembangan. Hasilnya adalah sebuah konsep aplikasi interaktif digital portabel yang memandu pengunjung pada situs-situs sejarah di Jakarta.
\end{abstract}

Kata kunci: Batavia, digital, historis, interaktif, media, Jakarta, Kota Tua, pariwisata.

\section{Introduction}

Jakarta's history dates back from the $4^{\text {th }}$ century when it was part of the Kingdom of Sunda. The first European encounter started in the $15^{\text {th }}$ century with the Portuguese establishment alongside the Sultanate of Banten. The Dutch took control of Jakarta from $16^{\text {th }}$ century, of which the original purpose was purely trading establishment for spices from the Moluccas, yet they remained here until the beginning of the $20^{\text {th }}$ century.

After the trading company Vereenigde OostIndische Compagnie (VOC) was dissolved in around 1800, the Dutch established the Dutch East Indies as a political colony, and started to develop 
Batavia as the main base or capital for the colony. The British ruled briefly at the beginning of this century, but Jakarta remained belonging to the Dutch for the rest of its European colonial rule.

The most interesting development happened during the Dutch rule, when the city was called Batavia, especially during the last century of colonial rule between 1850-1940. More comprehendsive documentations during this era exist today for the general public. The Batavia era was an important "transit point" in which Batavia planned and developed infrastructure carefully, laying a base for a capital city as we know today.

Geographically and politically, Batavia was divided into two townships, namely the Old Town in the north ("Old Town") and the New Town in the south. Between these townships, a main arterial street existed which we know today as Jl. Gajah Mada and Jl. Hayam Wuruk (then called "Molenvliet"). In the new town in the south, a large thoroughfare existed, which exists today as the Dataran Monumen Nasional (Monas), which was then called the "Koningsplein" ("The King's Square"). The new town was built in the areas today that constitute (but not limited to) the Dataran Monas, Pasar Baru, Senen, Salemba, Gondangdia/Cikini, and further south to Jatinegara (which was called "Mister Cornellis").

The Old Town is a popular tourist destination, because it has most of the remnants from the colonial era in one relatively convenient area. The Old Town area is a perfect example of a living museum, because it can be conveniently covered within walking distance, or only a short hop of human transport such as a bicycle.

Remnants outside the Old Town exist as well, but they are spread out and many of them are already demolished or converted into other establishments. The sheer size of the New Town makes it virtually impossible to reach every site by foot, and the aid of a motorized vehicle is inevitable.

Despite its potential and popularity, the Old Town is, by observations, underutilized and undermaintained. It is now located in intersections with busy traffic, thus, walking under a clean air is rarely possible. There is no clear signage system or guidance for visitors. Some museums, such as the Bank Mandiri museum, lack visitor guidance. Some of the buildings are dilapidated. More importantly, as a whole, the Old Town is disintegrated and has no system that connects them together.
It is crucial that we continue to conserve the Old Town before it disappears along future developments. The government has done so far with conservations, but collective efforts, such as independent initiatives, are necessary to achieve all the conservation goals and making sure that our future generations can still observe these historical vestiges to learn from them.

\section{Research Method}

The method used for this research is the design of an interactive digital media prototype that will address the issue of connecting the heritage of the past in Jakarta's Old Town district with the realities of the present, which in turn can educate and inspire the future generations to continue conservation efforts.

\section{Discussion}

\section{Conserving through Placemaking}

Conserving historical sites is an important effort to preserve the past and understand the city's evolution. Several methods exist for this, one of which lies in the term "placemaking", an effort to "bring a new breath" or create new perspectives to revitalize a place. It can be rebuilding the place physically or formulating a theme for a place that will give new meanings or relevance. The latter includes constructing a new interesting story, conversation or connection to specific themes that relate strongly to the place. The story, conversation or connection can be presented in a system, through multitude of interfaces that are directly "touched" by the visitors, such as with physical signage system, personal digital devices, or a live human guide. It is an integrated effort and can be in many forms working together.

Currently, visitors who are in Old Town are not presented with clear story or scenario as how one site relates to another. These locations are rather separate entities, and the visitors are forced to make a relation themselves through their independent research and actions. In short, the Old Town needs a story, and storytelling is an essential part for placemaking.

Storytelling includes phases for telling a story, which involves plots that runs through an opening, turning points, twists, single climax or multiple climaxes and ending. However, not every story has all these elements and runs through the same sequence. In interactive media, the audience is given the freedom to interact with one or all of the elements and is encouraged to create their own 
small stories. Conclusively, in interactive media, a story is not merely a sequence of events, but also a series of decisions, actions and responses (Quesenbery \& Brooks, 2010).

Interactive media is indeed a versatile way to aid with developing and communicating stories, and thus it is relevant for placemaking. The advent of new channels that interactive media can be delivered through, such as mobile technologies and the internet, has made it possible for stories to be shared almost instantly, simultaneously and efficiently.

Even without placemaking efforts, cities around the world have developed into "sentient cities". This concept basically means that the cities are "interacting" with the people in the city. This concept is brought by the ubiquitous nature of technology: it is always on, always available and accessible, and continue to feed data that influences our decisions in the city. The citizens are getting much more in touch on what is happening in the city based on these feeds, which influences their decisions to interact with the physical world, and in turn, shape the way the city would respond to them, architecturally and environmentally.

This has given us the potential to take part as a human and help direct the way we influence the city and the way it is influencing us in return. There is definitely a direct relation between conservation, placemaking and information technology.

\section{Heritage Tourism}

Recently, we are also driven by a tourism perspective called responsible tourism. A declaration was made in Cape Town in 2002 during Cape Town Conference on Responsible Tourism in Destinations, attended by 280 delegates from 20 countries, as part of World Summit on Sustainable Development in Johannesburg in 2002. According to this declaration, in page 3 of the documentation, responsible travel is expected to reduce "negative economic, environmental impacts"; brings "greater economic benefits, improves working conditions and access to the industry"; encourage participation of local people in "decisions that affect their lives and life chances"; introduces "positive contributions to the conservation of natural and cultural heritage, to the maintenance of the world's diversity"; delivers "more enjoyable experiences for tourists through more meaningful connections with local people, and a greater understanding of local cultural, social and environmental issues"; supports "access for physically challenged people"; and lastly, "is culturally sensitive, engenders respect between tourists and hosts, and builds local pride and confidence." Bringing historical tourism in Jakarta definitely covers most of the characteristics of responsible tourism.

There is clearly a major opportunity to fill in this area, and the advent of networked information technology, digital media products and the highly mobilized society provide multitude of opportunities in the tourism industry, where movements towards independent, sustainable and responsible travel are imminent.

Jakarta's historical aspect has always been a highlight of its tourism campaign. In the "Enjoy Jakarta" campaign, the Old Town is advertised as a tourist attraction.

There has also been numerous volunteer-based and self-initiated historical tours in Jakarta, which not only focuses in the Old Town area, but also larger context, like Chinese heritage trail or parks excursion.

However, without a human guide, it is almost impossible to learn and navigate through Jakarta's historical sites independently. There is hardly any standalone information signage system or travel publication that addresses this context. The availability of literary works covering Jakarta's history is scarce, and most of them are old documents not available to the larger Indonesian audience. Several contemporary literary sources exist, but they are not geared towards tourism.

Robert Silalahi, once the Director for Jakarta Tourism Board, agreed that Jakarta to return to historical tourism, in a quote he said in a national newspaper. Specifically, he said Jakarta should return to heritage-based tourism, such as the 795hectare Old Town and the "China Town" (presentday Glodok). Adolf J. Heuken, a Jakarta historian, believed that the core uniqueness of the city lies in its historical heritage, and thus it is important to preserve it.

\section{Tourism Insights: Indonesia and Jakarta}

Generally speaking, the tourism industry of Indonesia is sound, consistent and motivating. According to Badan Pusat Statistik, in a five-year period from 2004 to 2009, tourism revenues are one of the top six contributors to the national total revenues. In 2009, it is the third largest contributor of the national revenues just under oil and gas. It contributes around $10 \%$ of the total national revenues in 2010 with a number of USD7.6 billions/Rp70 trillions. 
The number of international tourists to Indonesia was $7,002,944$ visitors in 2010, consistently increasing from 2009 and 2008 respectively. Each tourist spends around USD135,01/Rp1,2 millions per day in pocket money, with a visit duration of eight days (average) and the total spending average of USD1,085.75/Rp10 millions total.

However, these numbers are mostly behind other country destinations in the region of Southeast Asia, particularly among the ASEAN member states (2011). Singapore received 9.7 millions visitors in 2009 alone, with 16\% growth accumulatively since 2005. Malaysia received 24.6 millions visitors in 2010 alone, with a staggering $125 \%$ accumulative growth since 2000 . Thailand received 16 millions visitors in 2010 alone, with a notable $30 \%$ growth accumulatively since 2005 . If we look at the tourism revenues in total, Thailand led with USD19 billions in 2010, Malaysia followed with USD17.75 billions in 2010 and Singapore, as a citystate, reaped a considerable USD9.8 billions.

For Jakarta alone, the number of visitors coming to the city is around $27 \%$ share of the total visitors to Indonesia annually (2010), and the SoekarnoHatta International Airport accounts for about 150,000 foreign visitors a month or about 1.8 millions annually, second after Ngurah-Rai International Airport in Denpasar, Bali (2010). The total tax revenue received from tourism industry is around USD205.37 millions, increasing 14\% from the previous year, 2009 (2010). Domestic tourism increased steadily since 2001 with a consistent growth percentage of 8\%-10\% annually (2010).

Again, compared to the capitals of the leading ASEAN member states, Jakarta is hardly a favorable destination. According to a report by Euromonitor International in 2009, the number of foreign visitors to the city ranks $64^{\text {th }}$ out of a 100 cities surveyed, compared to second for Bangkok, third for Singapore, fourth for Kuala Lumpur.

Travel competitiveness also falls short for the whole Indonesian republic, according to World Economic Forum's report titled Travel \& Tourism Competitiveness Report. Indonesia ranks $74^{\text {th }}$ out of a total of 139 states surveyed (2011).

The data clearly call for attentions for all stakeholders to continue innovating for Jakarta tourism in particular. Exponential action plans must be set to find the perfect "packaging" for Jakarta as a destination.

In the last decade, Jakarta has been branded "Enjoy Jakarta", a tourism campaign initiated by the city government. The campaign encompasses the many dimension of tourism, including a campaign to "See and Do", which includes "outdoor \& adventure", "culture \& heritage", "nature \& environment", "health \& wellness", "entertainment", and "shopping". It also includes recommendations on culinary highlights and tours. However, it is not clear what single, powerful message this campaign is trying to deliver related to Jakarta. The word "enjoy" is an oxymoron to what Jakarta is synonymous to.

Several research on perception and city branding do not come to Jakarta's favor. Out of 215 cities surveyed, Jakarta ranks $142^{\text {nd }}$ in the Most Livable Cities in the World index, a study conducted by Mercer Consulting in 2006 and 2007 respectively. A domestic research by the Ikatan Ahli Perencanaan Indonesia (Indonesia Planners Association) in 2011, called "Indonesia Most Livable City Index", ranks Jakarta $13^{\text {th }}$ out of 15 cities surveyed, taking into account the quality of life in Indonesian cities, which includes several parameters, which includes parameters relevant to tourism industry such as the quality of recreation facilities, public service information, quality of pedestrian walks, quality of roads, environmental pollution rate, public spaces availability and the quality of city planning.

A correct representation of Jakarta must be developed and it is part of the ongoing evolution of Jakarta as a brand. A city in itself is not a fixed product, it is "a dynamic, evolving place" (Nanda, 2011).

\section{Heritage Tourism}

There are about 21 sites in the Old Town documented in this research. These sites are selected based on the degree of significance and relevance, taken from literature studies, particularly from the works of Scott Merillees (in 2000 and 2012). The sites are not necessarily inside the original Old Town or walled city. Some outside the walled city have been identified to suggest relevant excursions within walking. short public transport or cycling boundaries.

1. Luar Batang Mosque

2. The Old Port of Sunda Kelapa

3. Pasar Ikan (Fish Market)

4. The Maritime Museum

5. Syahbandar Tower

6. Kota Intan Bridge

7. Kali Besar River

8. The Zion Church

9. The Wayang Museum

10. Fatahillah Square 
11. Museum of the Ceramics and the Arts

12. Fatahillah Museum

13. Cafe Batavia

14. The Red Shop

15. Bank Chartered Building

16. Bank Indonesia Museum

17. Bank Mandiri Museum

18. Jakarta Kota Train Station

19. Glodok and Pinangsia Area

20. Petak Sembilan

21. Jin De Yuan (Temple of Dharma Bhakti)

\section{Product Design Analysis}

Tourism industry is moving towards a new perspective that promotes sustainability and independence. Since the coming of independent travel guides, people have been traveling on their own. Publishers of travel guide books such as Lonely Planet, Fodor's, Frommer's, Moon and Let's Go have inspired people to go on their own and avoid time-consuming tours offered by major travel agents. People have the freedom to select their own itineraries and measure their own budgets. These make sure that their itineraries are tailored to their own needs.

The "golden age" of printed travel guide books were in the decades of the 1980s and 1990s. The 2000s saw a change in the formats of these travel guides. The availability of relatively affordable yet personal digital devices have shifted the focus from paper to digital. The shift is not just about format, it is more about habit and access. Conventional travel guides are facing fierce competitions from the massive availability of free information online, particularly from wiki-based sites like Wikipedia and Wikitravel. Online travel blogs offer focused and specialized insights. Social media sites are utilized to share and mine data. Web-based applications are utilizing information already freely available online to create a new genre of application called "mashup".

According to a short email interview with seven frequent travelers in Indonesia and Malaysia, aged between 20 s and 30 s, the simultaneous and rapid nature of internet access has changed the habit of travelers in terms of planning their trips. They can have more spontaneous journeys. Planning has become a stage where "big pictures" are framed, while the details are decided during the journey. They can even have an entirely different experience on the journey outside their original plan.

Mobile technology usage is inherent in traveler's life, which details in the use of mobile web browser and native applications. This has resulted in the ubiquity of mobile devices. Mobile devices have complemented, if not replaced, the availability and usage of traditional printed books and other means of tourist information, such as signage systems. It has also given opportunities for travelers to connect with each others and feed information. With such ubiquity, and the universal access it promotes, tourism experience has become a more personal yet at the same time, a social experience. Every individual has a different personal experience from the others and mobile technology has made it even more possible to share the experiences.

Digitizing travel guide books is just one way the shift from paper to digital is happening. Publishers, surely, have begun to convert their printed guide books into digital format, whether it is web-based or a native application, and porting them into mobile devices, which includes phones and tablets. However, there are more novel approaches to digital travel applications, which includes adding the social aspect of technology, by utilizing social media channels or creating their own social channels. Other innovation includes using the inherent hardware and software features such as augmented reality, QR (Quick Response) code and NFR (near-field communication). Some others even have mixed the conventional and the digital: they use physical signage systems or physical features to feed or complement information in their digital applications. Several of the examples are outlined below.

"I amsterdam" (www.iamsterdam.com) is particularly inspiring. With the help of Amsterdam Tourism \& Congress Board (ATCB) and Edenspiekerman - a world-known design agency - the city government of Amsterdam developed an interactive city exploration mobile application that helps visitors understands lesser known attractions. There is a total of 140 locations surveyed and now available for the application. The collaboration puts physical signage systems adjacent to each attraction with short paragraphs and $\mathrm{QR}$ code printed on them. These signages are made from handmade ceramic tiles to withstand outdoor conditions and reflect a Dutch identity. People without a QR codeenabled device might read the short paragraphs, while those with an enabled device can scan the QR code through an accompanying "I amsterdam" app that will tell you more about the specific attraction, a unique story that you might never heard of. Altogether, it weaves a more detailed story of a city than you would ever imagine. If sounds or videos are added, touring a city independently will make this application more immersive. 
Another good example of simple city touring application is Guardian's Streetstories app featuring the King's Cross area in the city of London, United Kingdom. Available for Apple iOS and Android devices, it takes users on a focused independent tour at King's Cross, an area in central London with a mixed history and an important rail hub. It doesn't tackle the whole city, but it tackles the specific area in a very detailed manner. Visually on the map, we will see several colored circles. In manual mode, when clicked or active, these circles will play the story relevant to a street, a building or any place. In automatic mode, a feature called "Autoplay" will track our location via global positioning system and plays the relevant audio guide automatically. We can imagine walking on the routes and begin listening to the story as we walk pass by a building or a street. The audio will fade away when we leave that particular area.

The third example is not necessarily touristoriented, yet is still related to way-finding. "GoThere.sg" is a Singapore-based transportation directory that automatically calculates the shortest and best-fared routes on a public transport from one point to another in the Singapore island.

Meanwhile, an independent Manchester-based travel website called "Creative Tourist" created a special city guide app that caters to museums and art galleries. In this simple iPhone app, users can view basic information of a museum or gallery such as history, opening times, contact and events, as well as going on a recommended trail from a select few.

\section{Product Development}

The method used to design the product is iterative design. Iterative design is a design process whereby a product is designed in cycles. In each cycle, the product is refined through testing and evaluations. The tests and evaluations can be done through prospected user testing or other evaluation methods (Nielsen, 1993). Over time, the result of each cycle of testing and evaluation will be accommodated to the next cycle. Between these cycles, stages of "finalized" products will be released.

Product development is divided into three major phases.

The first phase is discovery. In this phase, the background of the research is gathered, including the theories, case studies and statistics presented in the beginning of this paper.
The second phase is prototyping. In this phase, the product is heavily iterated over several cycles. The product will be evaluated using sample pool of users and usability analysis. Each cycle is called a "draft design".

The third and final phase is detailed design. In this phase, there will be enough iteration cycles to be comfortable with releasing a product, and the architecture, aesthetics and usability are all finalized and a prototype is born.

\section{Visual Design}

The visual design mimics a travel journal or has a similar theme, nostalgic color theme and focuses on simplicity, freshness and novelty. It should also formulate the main art and design style during the era, of which was predominated by art deco, especially in the $1920 \mathrm{~s}$. Other themes that are relevant are adventure and journey-based The design motivates the users to physically visit the sites, leverages the nostalgic aspect of the whole journey, has a clear hierarchy and promotes straightforward user interaction. The whole product should be unified in theme, simple in its form factor and focused on the practicality of travel.

\section{Product Concept}

Web-based application is the chosen format for the product because the web is independent of specific hardware and software requirements, which means it is accessible from any device with a browser; it is a solution that offers the ability to develop once, but deploy anywhere, which means it maintains a single or a few sets of code base but the resulting product can be accessed from a wide array of platforms, including mobile devices; is omitting the need to install or purchase applications; and in the case of mobile access, the web lets designers focus on user experience; and statistics show that mobile web-based sites still have the most usage percentage in comparison to their native counterparts (Wroblewski, 2011). In addition, Wroblewski also stated that the learning curve is easier for programmers and designers to step in to the web if compared to starting with native applications.

The product will comprise of two forms: desktop and mobile web formats. The desktop serves as a semi-immersive channel that contains the full information and multimedia features, in which the users can have a full-fledged experience to study and enjoy more of the historical sites. The mobile web formats invite actions, which are portable channels through which the users can interact 
directly with the historical sites. Both formats will be unified in a single platform.

The mechanism of this application is as follows:

1. User accesses the site from a URL.

2. User registers personal details and create an account. This will be short and only used to capture field data.

3. User reads or navigates through the content on their desktop devices.

4. User navigates to the intended historical site and read its story through an array of multimedia features such as text, audio (optionally downloadable) and images.

5. User feels the need to be present in certain historical location in Old Town Jakarta. User can access information on the mobile web version on their mobile devices.

6. User is compelled to do the action, on their mobile devices. The action is to virtually checkin to any of the historical sites and collect proof of presence, which is a digital stamps. Checking-in is limited to 100 meter radius, which is detected by the geolocation feature.

7. User collects the digital stamps in a virtual passport and can share their achievements with their friends in social media. Stamps can be viewed and shared from both desktop and mobile devices.

\section{Content}

The content is a curated list of highlights of Jakarta's Old Town, which includes around 21 sites. The name of the application is "Kelana Batavia". "Kelana" is "journey" in Indonesian language, and "Batavia" is the name of the original Jakarta. The content structure is as follows:

Buku Catatan/Notebook. This section contains basic information about Jakarta, such as its history, geography, arts, language, culture and the rest. It should give the user a basic understanding of Jakarta as a city.

Peta/Map. This section is a list of curated historical spots in Jakarta. With a focus in Old Town, where most historical sites are located, it will also expand to the rather spread historical sites in the larger New Town area, which begins southeast of Old Town.

Linimasa/Timeline. A real-time GPS-based guide that lets users record and annotate their journey with a map mashup of Jakarta, preferably using Google Maps.

Paspor/Passport. A colophon section that contains creator's information and software version.
Additionally, there will be parts that are dedicated to serve the content, which are the user registration mechanism, user assistance (help and languages), colophon and developer's contact information.

In its entirety, the application will be divided into two areas: the public and private areas. The public area is where users are not logged in or registered. The private area is where users are logged in and access all the four sections and do actions on their mobile devices.

\section{Prototyping}

Interface iterations have been done for the desktop and mobile web versions. There is also an information architecture scheme to complement the mockups.

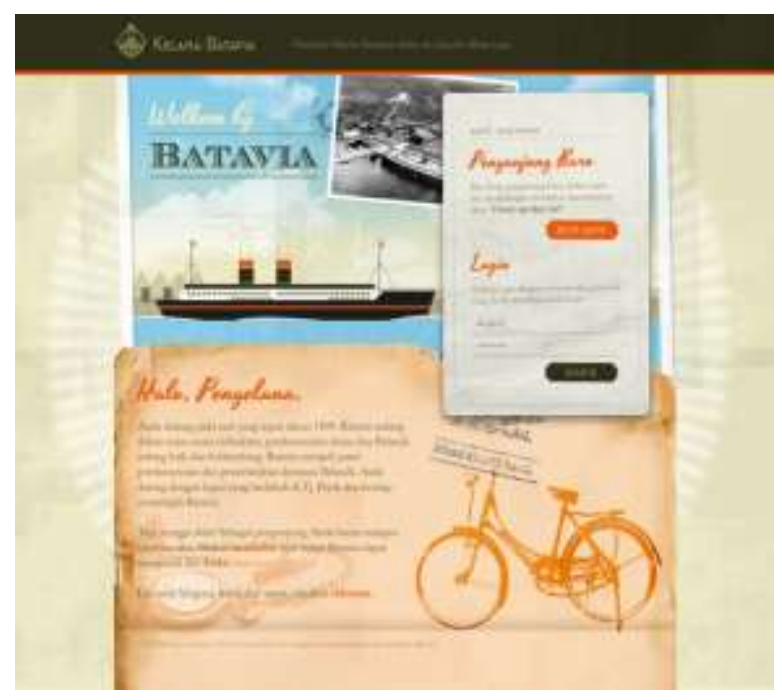

Figure 1. Public area interface

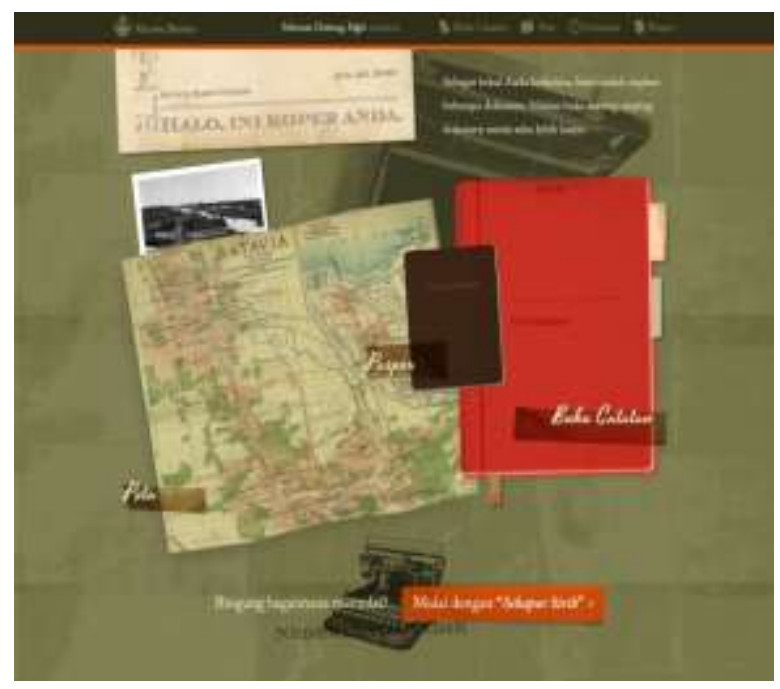

Figure 2. Private area interface, main menu 
Contents are still in dummy format because they need further development by content specialists.

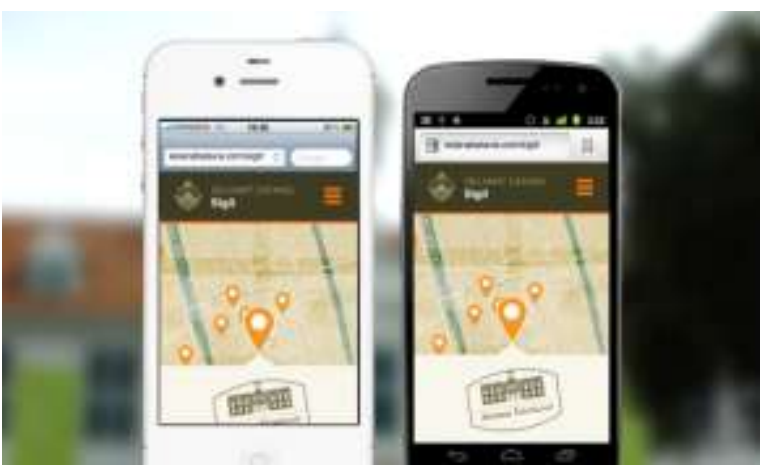

Figure 3. Mobile web version

Detailed artworks for the interfaces are provided in the Appendix section.

A static demonstration is available at the following URL: http://www.kelanabatavia.com. An introducetion to the concept is also presented in a video available in the the following URL: https://vimeo. com/42199169.

\section{Future Developments}

Future developments include:

1. Comprehensive content development which includes historical materials, visual materials and interface copywriting.

2. Backend programming deployment, preferably in an agile programming interfaces, such as Ruby on Rail or Hypertext Preprocessor (PHP) and MySQL.

3. Aural or audio content that lets users download audio stories.

4. Real-life connection with actual museums or management of historical sites in Jakarta, where they can exchange their virtual achievements for real-life benefits.

\section{Conclusion}

The exciting history of Jakarta, particularly in the Batavia era from the $17^{\text {th }}$ to $19^{\text {th }}$ century, can only survive if it is documented and presented in a sustainable way, one of which is through conservation. Conservation takes in many forms, including but not limited to initiatives called placemaking, which in turn create opportunities to develop places of interest that help tourism in the area. Self-guiding travel documentations are on the rise with the advent of digital mobile devices and the internet, giving efficiency of deployment and a wider audience, which contribute to placemaking effectively.
This research resulted in an interactive digital travel guide in the form of a web-based application for Jakarta's historical highlights. It serves the purpose of connecting the realities of the past and present, while helping us to imagine the future. This virtualguide motivates people to actually visit the sites and reconnect to the past, at a pace they define themselves.

\section{Acknowledgements}

The author would like to thank Biro Perencanaan Kerjasama Luar Negeri (BPKLN), Ministry of Education and Culture, Republic of Indonesia for the Beasiswa Unggulan scholarship that made this research possible, Dr. Intan Rizky Mutiaz for the valuable contribution and assistance and colleagues in Master of Design (Game Technology, Animation \& Digital Media) program in Institut Teknologi Bandung.

\section{References}

Anholt GfK-Roper City Brands Index. (n.d.). Last accessed December 14, 2011. http://www. simonanholt.com/Research/cities-index.aspx.

Association of South East Asian Nations. (2011, 1 Agustus). Table 28: Tourist arrivals in ASEAN as of 15 August 2011. Last accessed December 14, 2011. http://www.aseansec.org/stat/Table 28. pdf.

City of Cape Town. (2002). Cape Town Declaration. Last accessed March 8, 2012. http://www. capetown.gov.za/en/tourism/Documents/Respo nsible\%20Tourism/Toruism_RT_2002_Cape_ Town_Declaration.pdf.

Department of Tourism, Kingdom of Thailand (2010). Tourist Arrivals in Thailand 2010. Last accessed December 14, 2011. http://tourism.go.th/2010/th/statistic/tourism.p hp?cid $=30$.

Dyah, Anida. (October 3, 2012). Interview via email.

Enjoy Jakarta. (2010). Data Kunjungan Wisatawan Nusantara ke Jakarta Tahun 2001 - 2010. Last accessed December 14, 2011. http://www. jakarta-tourism.go.id/content/en/411/.

Enjoy Jakarta. (2010). Jumlah Kedatangan Wisatawan Mancanegara ke Indonesia Menurut Pintu Masuk, 2010. Last accessed December 14, 2011. http://www.jakartatourism.go.id/content/en/453/.

Enjoy Jakarta. (2010). Share Kunjungan Wisman ke Jakarta Terhadap Kunjungan Wisman ke Indonesia (Januari - Desember 2010). Last accessed December 14, 2011. http://www. jakarta-tourism.go.id/content/en/ 400/. 
Giovanni, Daniel. (October 13, 2012). Interview via email.

Heuken SJ, Adolf. (2007). Historical Sites of Jakarta. Cipta Loka Caraka: Jakarta.

Ichwandardi, Pinot. (October 10, 2012). Interview via email.

Ikatan Ahli Perencanaan Indonesia. (2011). Indonesia Most Livable City Index 2011. Last accessed December 14, 2011. http://www.iap. or.id/_data/download/MLCI\%202011.pdf.

Iskandar, Asteria. (October 5, 2012). Interview via email.

Kementerian Pariwisata dan Ekonomi Kreatif Republik Indonesia. (2011). Perkembangan Wisatawan Mancanegara Tahun 2000 - 2010. Last accessed December 14, 2011. http://www. budpar.go.id/filedata/5890_2068-updatewebstatsparFeb2011.pdf.

Kementerian Pariwisata dan Industri Kreatif Republik Indonesia. (2011). Perkembangan Wisatawan Nusantara (WISNUS) Tahun 2004-2010. Last accessed December 14, 2011. http://www.budpar.go.id/page.php?ic=521\&id $=5428$.

Kementerian Pariwisata dan Ekonomi Kreatif Republik Indonesia. (2009). Ranking Devisa Pariwisata Terhadap Komoditas Ekspor Lainnya Tahun 2004-2009. Last accessed December 14, 2011. http://www.budpar.go.id/ filedata/5436_1695-Rankingdevisa.pdf.

Maharani, Esthi. (2010, 23 September). Pariwisata DKI Terpuruk Akibat Kualitas Lingkungan Buruk. Republika Online. Last accessed December 14, 2011. http://www.republika. co.id/berita/breaking-news/metropolitan/10/09/ 23/135924-pariwisata-dki-terpuruk-akibatkualitas-lingkungan-buruk.

Mercer Consulting. (2011). 2011 Quality of Living survey. Last accessed December 14, 2011. http://www.mercer.com/press-releases/qualityof-living-report- 2011.
Merillees, Scott. (2000). Batavia in Nineteenth Century Photographs. Jakarta: Edition Didier Millet.

Merillees, Scott. (2012). Greetings from Jakarta: Postcards from a Capital 1900-1950. Jakarta: Equinox Publishing.

Merillees, Scott. (2 Maret 2012). Verbal interview.

Mimi. (2 Oktober 2012). Interview via email.

Nanda, Girish. (2011, 11 Mei). Brand Jakarta Not Delivering. The Jakarta Globe. Last accessed December 14, 2011. http://www.thejakartaglobe. com/opinion/brand-jakarta-not-delivering/440 314.

Prabowo, Reza. (5 November 2012). Interview via email.

Project for Public Spaces. What is Placemaking?. Last accessed January 21, 2012. http://www. pps.org/reference/what_is_placemaking/.

Smart Online, Inc. (2012). Smartphones pass PC sales for the first time in history. Last accessed November 15, 2012. http://www.smartonline. com/smarton-products/smarton-mobile/smartphones-pass-pc-sales-for-the-first-time-inhistory/.

Singapore Tourism Board. (2009). Annual Report on Tourism Statistics 2009. Singapore: Singapore Tourism Board.

Sari, Amalia. (October 3, 2012). Interview via email.

Syahrani. (October 3, 2012). Interview via email.

Twitter Blog. (2010). Twitter Blog: The Evolving Ecosystem. Last accessed November 15, 2012. http://blog.twitter.com/2010/09/evolving-ecosystem.html.

Wroblewski, Luke. (2011). Mobile First. New York, NY: A Book Apart.

Zazzle. (2013). Vintage French Eiffel Tower Paris Postcard. Last accessed January 8, 2013. http://www.zazzle.co.uk/vintage_french_chic_e iffel_tower_paris_postcard-239739455386629 899. 


\section{Appendix}

\section{Information architecture}

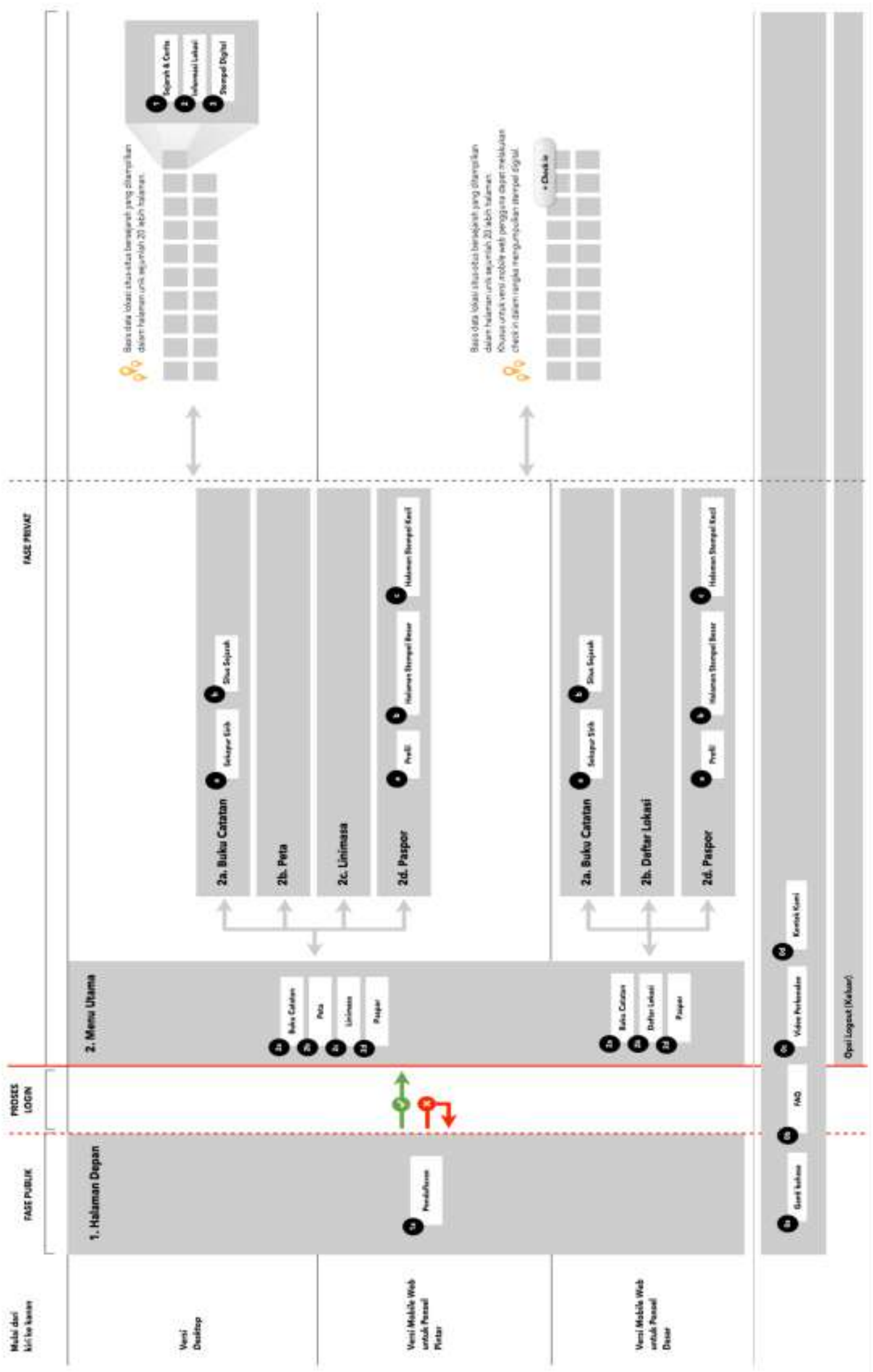




\section{User scenario}

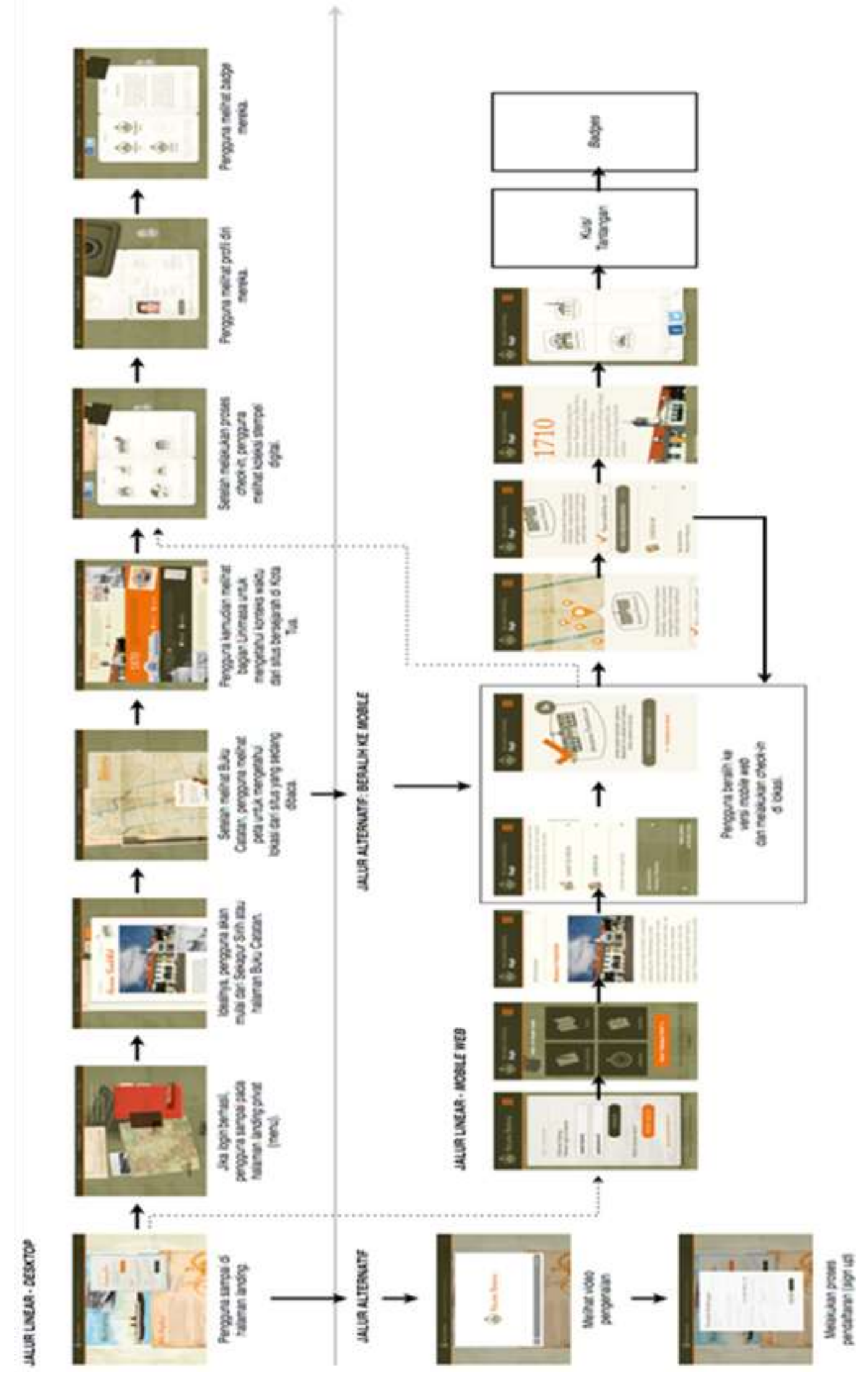

